\title{
WHERE DO RESOURCES COME FROM? THE ROLE OF IDIOSYNCRATIC SITUATIONS
}

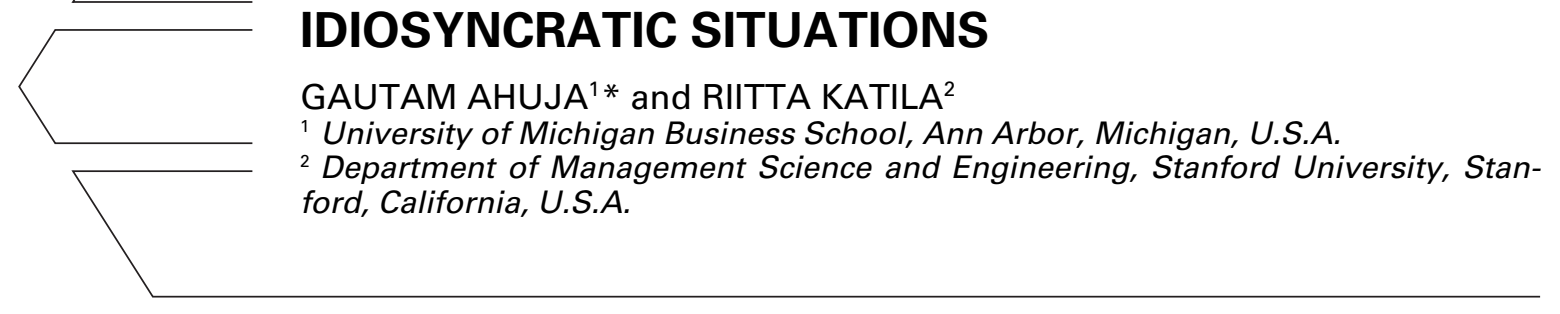

\begin{abstract}
In this paper, we examine the emergence of resources. Our analysis of technological capability acquisition by global U.S.-based chemical firms shows that the emergence of resources is inherently evolutionary. We find that path-creating search that generates resource heterogeneity is a response to idiosyncratic situations faced by firms in their local searches. Two such idiosyncratic situations - technology exhaustion and expansion beyond national markets-trigger firms in our sample to create unique innovation search paths. We also find that along a given path firms experiment in order to find the correct investment-in fact, some organizations seem to take a step backward for two steps forward-further demonstrating the evolutionary nature of the resource creation process. Copyright $\subset 2004$ John Wiley \& Sons, Ltd.
\end{abstract}

The resource-based view of the firm is one of the most prominent theoretical perspectives in strategic management (Wernerfelt, 1984; Barney, 1991; Teece, Pisano, and Shuen, 1997; Eisenhardt and Martin, 2000; Helfat and Raubitschek, 2000). Central to this perspective is the idea that firms differ in their resource positions, and that such resource heterogeneity is a source of performance differences across firms (Barney, 1991; Peteraf, 1993). In fact, resources are defined as those attributes of physical and knowledge-based assets that enable a firm to conceive and implement strategies that lead to differences in performance (Wernerfelt, 1984). Recent empirical work on resources has been vibrant. For example, researchers have shown that firms can sustain heterogeneous resource positions over time (Helfat, 1994; Knott, 2003), and that these heterogeneous resource positions explain

Keywords: innovation; resources; science; geographic boundaries

*Correspondence to: Gautam Ahuja, University of Michigan Business School, 701 Tappan Street, Ann Arbor, MI 48109-1234, U.S.A. E-mail: gahuja@umich.edu why firms perform differently (Henderson and Cockburn, 1994; Iansiti and Clark, 1994; Berman, Down, and Hill, 2002; Knott, 2003; Zott, 2003).

Yet, the research has provided only partial guidance on how these heterogeneous resource positions are born. While factors such as initial endowments and prior commitments (Eisenhardt and Schoonhoven, 1990; Helfat and Lieberman, 2002), timing (Stinchcombe, 1965; Zott, 2003), and managerial capabilities (Knott, 2003) each provide intriguing explanations for heterogeneity, these answers still beg the question of how these positions were initially acquired. The question thus still remains: Where does resource heterogeneity come from?

In this paper we draw upon evolutionary theory to identify possible sources of the origins of resource heterogeneity. We propose that heterogeneity in resources can be created as a response to idiosyncratic situations (Holland, 1975; Nelson and Winter, 1982). We argue that firms respond to idiosyncratic problems and opportunities facing them by embarking on new search paths. The 
creation of such new paths is the cornerstone of resource heterogeneity. While previous work has examined how inertia (Fredrickson and Iaquinto, 1989; Helfat, 1994) and momentum (Miller and Friesen, 1980; Amburgey and Miner, 1992) sustain change along pre-existing paths (path-deepening search), we know much less about how these paths emerge in the first place (path-creating search), and whether such created paths can promote sustainable performance differences across firms. Identifying the determinants of path-creating search and understanding the performance implications of the resultant resources are the two research objectives of the study.

We test our framework of resource heterogeneity in the context of the technological capability search activities by global U.S.-based chemicals firms. We identify two types of idiosyncratic situations - technological exhaustion and market expansion-that lead to path-creating search. Firms that are inventing in arenas where the technology is well exploited are driven to search scientific knowledge to acquire fresh raw material (science search). Similarly, firms that are entering new international product markets are driven to expand international research to address local opportunities and problems (geography search). Second, we find that, at moderate levels, resource heterogeneity that arises from the science and geography search enhances subsequent patenting of chemical firms. In sum, we propose an integrated framework that demonstrates not only the performance outcomes associated with resource heterogeneity, but also offers an explanation of how the firms that benefited from these resources came by them in the first place.

Our results extend existing work on resources. The role of resource heterogeneity in underpinning performance differences has been established in the conceptual literature and has also been empirically validated to some degree (e.g., Henderson and Cockburn, 1994). However, few researchers have studied how resource variations themselves emerge. Thus, this paper responds to calls in the literature for strategy researchers 'to move beyond studies of differential performance to more integrated studies which not only identify those factors that are correlated with superior performance but also attempt to explore the origins and the dynamics of their adoption' (Cockburn, Henderson, and Stern, 2000: 1124). In this study we draw upon evolutionary theory to suggest that variations in idiosyncratic situations faced by firms can eventually lead to the development of resources that improve performance.

Our results also address intriguing questions about the dynamics of organizational change. We find that the acquisition of technological capabilities is inherently evolutionary: firms experiment to find the correct investment along a given search path, and frequently make mistakes, both undershooting and overshooting the most productive levels of search. In fact, organizations that search the geography space appear to take a step backward for every two steps forward.

We also contribute to the burgeoning literature on evolutionary search (Nelson and Winter, 1982; Helfat, 1994; Podolny and Stuart, 1995; Rosenkopf and Nerkar, 2001; Katila, 2002; Katila and Ahuja, 2002). We extend prior work in this stream in several ways. First, prior research on search has emphasized the role of local search; i.e., new searches by firms are likely to be constrained to the areas in the neighborhood of their current searches and eventually result in convergence of search approaches (e.g., Cyert and March, 1963; Stuart and Podolny, 1996). In this study, we follow the lead of more recent literature that suggests that many successful firms proceed beyond local search to enhance their resource positions (e.g., Rosenkopf and Nerkar, 2001; Hargadon, 2003). We identify situations that drive firms to break away from local search. Second, search researchers have focused largely on the degree to which firms search across the landscape of possible technologies to develop knowledge-based resources (Nelson and Winter, 1982). In this study we identify two additional dimensions that help firms proceed beyond technologically local search: the degree to which they search the science base, and therefore cross the technology-science boundary (e.g., Cockburn et al., 2000), and the degree to which their search crosses geographic boundaries and is thus non-local in the spatial sense (e.g., Almeida, 1996).

\section{THEORETICAL BACKGROUND AND HYPOTHESES}

In this study, we examine the antecedents and consequences of resource heterogeneity by focusing on two dimensions of innovation search. One is 
scientific. Firms search the science base to overcome the limitations of their current technology base. The second dimension of search is geographic. Firms search across geographical boundaries to expand their technology base and to solve local technological problems. We discuss both dimensions in more detail below.

Science is the establishment of facts and the development of quantitative rules or laws that relate those facts to each other (Allen, 1977). The goal of scientific activities is to enhance knowledge and understanding, or learning for its own sake. Technology, in contrast, is concerned with incorporating such knowledge into physical artifacts that benefit users. Although, for example, Nelson and Winter (1982: 229) recognize the role of science in the process of innovation search, they model it as a sector-specific influence that determines the likelihood of search resulting in the discovery of new technologies in a given sector. Such an abstraction is useful, yet the treatment of science as an exogenous source of technological enrichment obscures an important reality. Scientific developments do not naturally and costlessly sweep across a sector and enrich the search efforts of all firms in the same manner. Just as firms need to search across the technological landscape, they need to actively monitor and exploit scientific developments (Henderson, 1994; Henderson and Cockburn, 1994; Zucker, Darby, and Brewer, 1998). To the extent that active exposure to the science base does enrich innovation search efforts, such variations could have an impact on resource heterogeneity and subsequent performance.

Geography search - the degree to which a firm's search efforts span national boundaries (Almeida, 1996; Hansen, 1999; Feinberg and Gupta, 2004) also provides an opportunity to expand the variety in the firm's resource base. For many firms, technology search efforts are restricted to a single nation. For others, such efforts may span several nations. Such differences are important in the context of innovation because, increasingly, research suggests that the technological landscape is differentiated across geographic space (Freeman and Soete, 1997; Katila and Ahuja, 2002; Hansen and Lovas, 2004). Idiosyncratic national circumstances and institutions induce local, regionally distinctive, and partially insular development of technology resources (Lundvall, 1988). Distinctive cultural influences and physical and institutional infrastructures often impose their own pressures and imprints on the avenues that are actively pursued in technological development in any nation. Thus, the precise elements of the technological domain that are addressed and developed in a given nation may vary from those that are developed in other nations (Porter, 1995). By crossing geographic boundaries firms can obtain access to these variegated technological trajectories.

In the hypotheses that follow we draw upon evolutionary theory to explain the sources of resource heterogeneity in science and geography search. Specifically, we propose that path-creating search that generates resource heterogeneity is a response to idiosyncratic situations (both problems and opportunities) faced by firms in their current local searches (Nelson and Winter, 1982). We then examine the second component of our integrated framework, that is, how these search variations change the innovative performance of firms.

\section{Antecedents of resource heterogeneity}

Evolutionary researchers identify two circumstances through which new search paths for resources are created. The first circumstance is the unexpected problems that arise during local search efforts in the form of puzzles or boundary conditions (Nelson and Winter, 1982; Nelson, 1995). The second is the unforeseen opportunities that arise from unexpected situations (Meyer, 1982; Martin and Eisenhardt, 2002). We examine both problems and opportunities in the context of science search first, and then proceed to geography search.

\section{Science search}

From the problem-driven perspective, firms will expand science search when the current technological area where they operate is reaching its limits. Innovation often occurs through the combination and recombination of existing elements into novel artifacts (Utterback, 1994; Galunic and Rodan, 1998; Hargadon and Douglas, 2001). However, over time, unless the elements available for recombination are increased in some fashion, the tempo of innovation must decline as the recombinant search space is exhausted (Hargadon and Sutton, 1997; Fleming, 2001). Thus, as the elements in a given technological domain are increasingly exploited and their potential for subsequent 'new' recombination declines, firms that are active 
in that technological domain must look beyond technology to enrich and reignite the invention process. Science would then be a natural candidate for attention.

Exhaustion of the technological domain also drives resource heterogeneity in the form of an opportunity. While several authors have documented that firms are reluctant to devote resources to science search (e.g., Henderson, 1994), idiosyncratic situations as described above can provide opportunities to justify such search. The observation that idiosyncratic problems represent opportunities for firms to change is confirmed by researchers who have examined how idiosyncratic incidents, such as problems or surprises, can change search patterns of individuals and groups (Meyer, 1982; Graebner and Eisenhardt, 2003). During these 'windows of opportunity' that represent timeouts from normal activities, individuals are more likely to become aware of alternative paths, and see a legitimate opportunity to bring up new alternatives (Tyre and Orlikowski, 1994; Okhuysen and Eisenhardt, 2002). Based on these observations, we propose that technology exhaustion represents a legitimate opportunity for firms to go beyond local technology search, and to search science.

The above arguments suggest that firms working in well-exploited technological domains, i.e., in domains where current inventive efforts build on many preceding inventions, are likely to search the science base more intensely in order to have access to a more heterogeneous resource base. Accordingly, we hypothesize:

Hypothesis 1: The greater the degree of technological exhaustion faced by the firm, the greater the intensity of its subsequent science search.

\section{Geography search}

Idiosyncratic problems and opportunities also drive innovation search across geographic areas. First, firms that are active in multiple national markets are likely to confront specific local problems in each market. Variations in user needs, manufacturing processes, or availability of materials may require adapting technology to local contexts or developing new technologies to solve local problems (Abernathy and Utterback, 1978; Dunning, 1992). For instance, variations in local environmental regulations or in resource availability may make certain manufacturing practices and processes impossible or unviable in some countries. Similarly, certain products may need to be modified to local specifications and needs. Raw materials may need to be substituted for and the resultant reformulation of the product may need extensive testing and approvals in the new environment. Cultural, administrative, and institutional variations may also necessitate product and process adaptation (Ghemawat, 2001). Supplying products in international markets may also entail the provision of ongoing technical support. Finally, transfer of technologies developed in the domestic market to international subsidiaries often requires absorptive capacity to manage and maintain that technology in the foreign unit (Dunning, 1992; Nobel and Birkinshaw, 1998). For all of these reasons, as a firm's international product market presence broadens it is likely to promote the broadening of its international research presence.

Second, expansion to new product markets may also present an opportunity to engage in geography search. Presence in a market often increases a firm's awareness and appreciation of locally developed technology, regional science and technology networks, and of the potentially lower costs for research activity in foreign sites (Granstrand, Hakanson, and Sjolander, 1992; Kuemmerle, 1999). The firm may then respond by expanding technological operations to the international site. Thus, expanding a firm's international productmarket footprint translates to several stimuli-both problems and opportunities - that are likely to encourage the expansion of its international technological presence. Accordingly, we hypothesize:

\section{Hypothesis 2: Changes in a firm's international product market presence will trigger changes in its international research presence.}

\section{Outcomes of resource heterogeneity}

The second component of our framework focuses on the performance effects of science and geography search. A natural domain for the investigation of the effectiveness of a firm's innovation search activities is its innovative performance. Innovativeness is naturally only one dimension of performance, yet an important one for hightechnology firms (Schoonhoven, Eisenhardt, and Lyman, 1990). 
From the evolutionary viewpoint, innovations share several common features. First, many innovations emerge because they are the locus of a meeting between a problem and its solution, even when neither the problem nor the solution is itself new (Cohen, March, and Olsen, 1972). For example, innovations often result from the recombination of known elements of various solutions (Holland, 1975; Galunic and Rodan, 1998; Hargadon and Douglas, 2001). Their novelty stems from the act of combination, not necessarily from the individual components that are combined (Henderson and Clark, 1990; Utterback, 1994). Second, innovations can also emerge because they represent some unique genuine novelty; the solution includes components or elements that did not exist earlier, and whose very existence is evidence of novel invention (Holland, 1975). Thus, innovations can emerge if they resolve existing problems in new ways - either through recombination or by including novel elements; alternately they can emerge if they solve new problems, i.e., problems that were hitherto unidentified, but which once identified have a commercially relevant dimension (Dougherty, 1992; Shane and Venkataraman, 2000). Other things being equal, activities that enhance a firm's exposure to new combinations of problems and solutions, or to novel problems or novel solutions, represent paths to improve the productivity of the firm's innovation efforts. Below we examine how science and geography search promote proceeding down each of these paths, and thus enhance the innovativeness of firms.

\section{Science search and innovativeness}

Searching science can improve innovative productivity through at least two mechanisms. First, science can influence innovative productivity by increasing the number of elements available for combinations. The recombinant search space, or the set of technological elements available for recombination, is finite. If no new elements are added to the search space recombination activity eventually exhausts the set of potential combinations (Kim and Kogut, 1996; Fleming, 2001). Using theoretical principles, science can identify new, original building blocks (Merton, 1957) that can be combined to produce similar functionalities through completely novel routes. For instance, Einstein's elucidation of the relationship between mass and energy identified the atom as a potential energy source, completely distinct from all known paths to the generation of energy. Since new elements that eventually lead to novel combinations often appear first in the scientific literature (Merton, 1957; Rosenberg, 1990), science search can play an important monitoring function (Prescott and Gibbons, 1993) for new ideas, and for new combinations.

Second, science can improve the inventor's understanding of cause-effect relationships and thus help identify the elements whose combination is likely to be fruitful (Freeman and Soete, 1997; Cockburn et al., 2000). For instance, in the 1960s and 1970s pharmaceutical drug research entailed large-scale screening of thousands of compounds in the hopes of discovering something new or effective. However, advances in the biomedical sciences of physiology and biochemistry ushered in the era of 'rational' drug design, where biochemical and physiological principles are used to focus on a few substances that are theoretically likely to yield the desired outcomes (Henderson and Cockburn, 1994). Scientific understanding of the cause-effect relationships between chemical substances and physiological outcomes gained through experience in science search reduced the number of combinations that needed to be tried for successful innovation (Cockburn et al., 2000).

Although exploring science can provide the above-mentioned benefits, excessive search of the science base is likely to be counter-productive from the perspective of innovation. First, scanning scientific literature, attending scientific conferences, and other exploratory or knowledgebuilding activities all demand significant time and resources. Time devoted to such activities must reduce the time available for actual integration and application of the knowledge elements obtained. Thus, excessive exploration to obtain new knowledge reduces the attention available for the task of exploiting it (March, 1991; Levinthal and March, 1993). At high levels, exploration tends to drive out exploitation altogether. An organization that excessively exposes potential innovators to science risks their losing sight of the ultimate goal of creating useful artifacts.

Second, since the success of science search is much more uncertain than that of technology search (Rosenberg, 1990), extensive searches of scientific knowledge may result in a random drift where a firm's knowledge bases are altered frequently in uncertain directions (Lounamaa and 
March, 1987). Such drift generates a selection of unrelated discoveries that are costly to integrate (Levinthal and March, 1993), and may even create paralyzing anxiety about the future that stops innovation but still entails search costs (Eisenhardt and Tabrizi, 1995). Innovativeness may also decrease since individuals often have difficulties readjusting their mental models in the face of extensive change caused by uncertainty (Barr, Stimpert, and Huff, 1992). The above arguments suggest that some exposure to the science base can increase innovation output, but excessive search of the science base may eventually decrease innovation output. Accordingly, we hypothesize:

Hypothesis 3: The intensity of science search will be curvilinearly (inverted $U$ ) related to the subsequent innovativeness of the firm.

\section{Geography search and innovativeness}

Recombinatory search for new innovations occurs only among the knowledge elements that a firm is aware of (Galunic and Rodan, 1998). Naturally, under conditions of perfect information and unlimited rationality, the existence of knowledge would be sufficient for all firms to be able to use it with equal facility, irrespective of location. However, when knowledge diffusion is imperfect and cognition is limited, what matters is not whether a piece of information exists in the world, but rather whether it is part of the cognitive set or knowledge base of the firm when it is needed (Hargadon and Sutton, 1997). International research units can be established specifically to address these imperfections in knowledge transfer.

Increasing international research presence, that is, geography search, can improve innovative productivity through at least two mechanisms. First, with their idiosyncratic histories and technological pursuits, a presence in multiple nations can raise a firm's awareness of the different areas of the knowledge landscape and thus provide a varied set of raw material for knowledge combinations (Pouder and St John, 1996; Kuemmerle, 1999). Multinational researchers have identified that rich communication channels that develop inside multinational firms in the form of interpersonal networks promote awareness of such specialized local knowledge (Gupta and Govindarajan, 2000; Almeida, Song, and Grant, 2002). Thus, firms that are proximate to the innovation may receive not only more diverse but also more current information than firms without a presence in the neighborhood.

Second, a research presence in multiple nations also links firms to multiple regional networks of knowledge faster than market mechanisms do (De Meyer, 1992). Knowledge is often held by local engineers and the identification, and the transfer and combination with knowledge acquired from other local contexts, is often made through network connections between such individuals (Almeida and Kogut, 1999). Prior research also indicates that geographic co-location and short path lengths (in a sense, small world structures created by multinational presence) facilitate the transfer of knowledge (Jaffe, Trajtenberg, and Henderson, 1993; Almeida, 1996; Hansen and Lovas, 2004).

However, scanning too widely across geographic contexts can also be dysfunctional. Integration problems increase exponentially with an increase in the number of nodes across which the integration is to be conducted. Distance, time zones, and national borders can exacerbate this problem of coordination (De Meyer, 1992; Hansen and Lovas, 2004). Decentralization of knowledge also intensifies the challenge of appropriating the organization's core knowledge from spillovers that may compromise the first-mover advantages in new technologies (Hood and Young, 1979; Katila and Mang, 2003). As the complexity of handling this diversity grows and the limits of bounded rationality are approached, these monitoring problems often overcome the benefits at high levels. Further, setting up research infrastructures in multiple nations is likely to lead to suboptimal scale operations at extreme levels, as resources are spread too thin. Thus, beyond a point, innovation search across geographic boundaries will face diminishing returns. Accordingly, we hypothesize:

\section{Hypothesis 4: The breadth of geography search will be curvilinearly (inverted $U$ ) related to the subsequent innovativeness of the firm.}

The above hypotheses summarize the relationships between the antecedents of resource search and its consequences for firm innovativeness. Together these hypotheses present an integrated framework that explains both why search varies 
across firms and the impact of such variations on firm innovative performance.

\section{METHODS AND MEASURES}

\section{Data}

The hypotheses of the study were tested with longitudinal data on the innovation activities of the leading U.S. chemical firms over the period 1979-92. We identified the key players in the U.S. chemical industry from lists that are published annually by trade journals such as Chemical Week and Chemical and Engineering News. To avoid any survivor bias we selected the sample from the lists at the beginning of the study period and attempted to obtain data on all firms over the entire period. However, the final panel is unbalanced as some of the firms were acquired by other firms or restructured in a fashion that made comparison difficult beyond a particular year. In such cases we included the firm for the period before its acquisition or restructuring.

The chemical industry is an appropriate setting for this research for several reasons. It is a global industry with both market and technological activity dispersed internationally. Market diversity and technological intensity also make it especially suitable for our study. Market diversity in the chemical industry is due to local differences in downstream products, customer bases, needs for technical assistance, and environmental regulations (Arora and Rosenberg, 1998; Landau and Arora, 1999). The chemical industry is also technology intensive (Klevorick et al., 1995). For example, in 1992 the U.S. chemical industry invested $\$ 16.7$ billion in $\mathrm{R} \& \mathrm{D}$, more than any other U.S. industry (Arora, Landau, and Rosenberg, 1998). Patenting is also important in chemical (Levin et al., 1987; Ahuja, 2000a). Accordingly, there is significant potential for innovation search in this industry on the search dimensions identified in this paper.

\section{Measures}

The theory presented in the previous section suggests several dynamic relationships between resource search and its antecedents and consequences. Obtaining the longitudinal data that are required to test these hypotheses is, in general, very difficult. However, patent data provide an opportunity

Copyright @ 2004 John Wiley \& Sons, Ltd. to examine the characteristics of innovation search over a relatively long period of time (Katila and Ahuja, 2002). Thus, patenting records are likely to be good indicators of the underlying innovative behavior of firms in our sample.

We use patent data from the United States Patent and Trademark Office database. To obtain patent protection for an invention in the United States, the inventor is required to apply for a U.S. patent, even if the invention was conducted overseas. Since the United States is an important market for most industrial goods, almost half of the patents issued in the United States reflect inventions created in foreign locations. Foreign subsidiaries of U.S. firms that are active in research routinely obtain patents for their overseas inventions in the United States. The U.S. patent data also give a consistent measure of the patenting activities of our sample firms, since all the firms are large, multinational chemical firms for whom gaining patent protection in the U.S. market is especially important.

To obtain the patent data, we prepared a list of all the divisions, subsidiaries, and joint ventures for each of the sample firms using Who Owns Whom and The Directory of Corporate Affiliations directories. Thereafter, each firm's history was traced through the study period to account for any name changes and reorganizations, and to obtain information on the timings of events such as the founding and dissolution of joint ventures. This master list of firm names was used to identify all patents issued to the sample firms. The granted patent carries the date of the original application, and we use this application date to assign patents to appropriate years as is customary in the patent literature (Griliches, 1990). In sum, there were over 40,000 patents issued to the sample firms over the study period.

Turning to the specific search measures, patent data provide a useful indicator of a firm's search across the science base (Carpenter, Cooper, and Narin, 1980; Narin, Hamilton, and Olivastro, 1997). Since a patent confers a property right on the 'new' knowledge created by the patent to the assignee of the patent, U.S. patent law requires that all prior contributions on which the patent builds be documented on the body of the patent. These cited references record the knowledge already existing prior to the creation of the patent. Thus, they serve to identify precisely the new knowledge created by the 
patent and delineate the domain on which the patentee is actually granted an intellectual property right (Walker, 1995). The references in a patent are separated into two categories based on the source of the prior knowledge used: (a) prior knowledge that was recorded in the form of another patent (patent references); and (b) prior knowledge that was recorded in other, non-patent sources such as scientific journal articles and commercial literature (the non-patent references). In prior research patent references have been used to relate patents to other patents and thus to identify linkages between technologies (Stuart and Podolny, 1996; Rosenkopf and Nerkar, 2001; Katila and Ahuja, 2002). In contrast, nonpatent references have been used to identify linkages between technology and science (Narin et al., 1997). We exploit the information on nonpatent references to identify links between the artifactual knowledge documented in a patent and the non-patented knowledge recorded in scientific publications.

Patent data also provide a good source for measuring the firm's search across geographic areas. The location of the inventor is documented in the patent and indicates the national origin of the patent. Thus, firms obtaining patents in many countries have a broader technological presence across nations than firms obtaining patents in a few countries. We provide more details on these search measures below.

\section{Dependent variables}

\section{Science search}

We used data included in the non-patent references to operationalize science search, i.e., the dependent variable in Hypothesis 1. We measure a firm $i$ 's intensity of search across the science base in

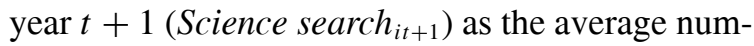
ber of scientific non-patent references in the firm's patents that year. To compute this variable we calculate the total number of scientific publications cited by a firm's patents in year $t+1$ and divide this number by the number of patents obtained by the firm in the same year. For a firm that obtains 100 patents a year and cites 50 scientific nonpatent references in them, this variable has a score of 0.5 . In order to separate scientific from nonscientific references, we followed procedures used in prior work (Narin and Noma, 1985; Narin et al.,
1997). We first categorized the non-patent citations (52,000 in our sample) into five categories: citations to scientific books, journal articles, conference proceedings, technical documents (such as foreign patent literature and standards), and commercial documents. A part of this categorization was accomplished through a computer program written for the purpose, but nonstandard input, name changes, and spelling differences forced us to do extensive hand-coding to complete the task. We then constructed the science search variable for each firm yearly by using the citations in the first three categories only. Our final science search variable includes citations to scientific books, journal articles, and conference proceedings; citations to non-scientific documents such as commercial brochures, patents, and standards are excluded. This variable is also used as an independent variable in equations predicting Firm innovation where it is used in a count form as the total number of journals, books, and conference proceedings in the previous year.

\section{Geography search}

The dependent variable in Hypothesis 2, breadth of geography search (Geography search $\left.{ }_{i t+1}\right)$, is measured through the firm's patenting across nations each year. We use Blau's (1977) index of diversity to construct this variable. The formula is $1-\sum_{j=1}^{c} p_{j}{ }^{2}$, where $p_{j}$ is the proportion of the firm's patents in country $j$, and $c$ the total number of countries. High scores suggest that the firm's search is geographically more diverse. The Blau index is widely used and highly correlated with alternative diversity indices (Bantel and Jackson, 1989). Since the dependent variable in Hypothesis 2 indicates changes in the breadth of geography search, we use the difference between the period $t+1$ and period $t$ values of the Blau index to construct this variable. This variable is also used as an independent variable in predicting Firm innovation where the variable is used in its original (i.e., levels, not changes) form. To determine the geographic location of each patent, we identify the location of the inventor documented in the patent. If the patent has many inventors, we follow the U.S. Patent Office and prior research convention (e.g., Trajtenberg, 2001) of using the first inventor to determine the country location. 


\section{Firm innovation}

We measured the dependent variable in Hypotheses 3 and 4, Firm innovation $_{i t+1}$, as the number of successful patent applications, or granted patents, for firm $i$ in year $t+1$. Using patents as a measure of innovative output follows several previous research efforts that have used patents as a measure of knowledge (Henderson and Cockburn, 1994; Ahuja, 2000a; Ahuja and Katila, 2001; Rosenkopf and Nerkar, 2001). Empirical studies find that patents are closely related to measures such as innovation and invention counts (Achilladelis, Schwarzkopf, and Cines, 1987) and expert ratings of corporate technological strength (Narin, Noma, and Perry, 1987). To measure innovative output we used the standard innovation production function approach (Griliches, 1979) in which the count of inventions is modeled as an outcome of the total inputs (for example, R\&D; see details below). For robustness we also supplemented our analysis of patent counts with additional analysis using citation-weighted patents.

\section{Independent variables}

\section{Technology exhaustion}

We captured the idiosyncratic triggers of Science search using the Technology exhaustion it $_{\text {variable }}$ (Hypothesis 1). This variable is measured as the average number of prior-art patents cited by a firm in its patents each year. Patents making more citations to prior art exploit existing knowledge more than develop new ideas (Podolny and Stuart, 1995; Ahuja and Lampert, 2001). Thus, firms that cite many patents as precursors of their own inventions are likely to be working in relatively wellexploited areas of technology and are more likely to face technology exhaustion than firms that cite only a few patents. Since technology exhaustion can lead to increased scientific search with a lag, we constructed four lagged versions of this variable reflecting its period $t, t-1, t-2$, and $t-3$ values (Ahuja, 2000b).

\section{Changes in international product-market presence}

This variable is used as a measure of idiosyncratic triggers of Geography search (Hypothesis 2 ). We first construct the international productmarket presence variable as the number of countries that each sample firm has a presence in through either a subsidiary or an affiliate company as recorded in the annual editions of the Who Owns Whom directories (Shaver, 1998). This variable is collected yearly from 1982 to 1992 for each company. Since in Hypothesis 2 we predict that changes in international product-market presence will lead to changes in geography search, we then compute the difference between the period $t$ and period $t-1$ values of the presence variable as the value of International product-market change ${ }_{i t}$. As above, since there can be a lag between changes in product-market change and its effect on search, we compute four alternative lagged versions of the variable reflecting the $t$ to $t-1, t-1$ to $t-2$, $t-2$ to $t-3$, and $t-3$ to $t-4$ changes. Note that including four lags significantly reduces our sample size as each lag implies a loss of a full year of data.

In predicting Firm innovation, Science search $_{i t}$ and Geography search $_{i t}$ are included as independent variables. Note that the study has a longitudinal design: the patents that form the basis for the dependent variables are distinct from the patents the independent variables are based on. The independent variables are based on patents from the previous year(s).

\section{Control variables}

\section{Science and geography search}

To control for path-deepening search, which is potentially an alternate driver of firm search behavior (e.g., Helfat, 1994), we include the one-period lagged values of science and geography search variables $\left(\right.$ Science search $_{i t}$, Geography search $_{i t}$ ) in the equations predicting Science and Geography search, respectively. Prior research on organizational inertia has employed a similar strategy of using the relationship between current and past values of the dependent variable as a measure of inertial tendencies (e.g., Helfat, 1994). In sensitivity analyses we also used the two-prior-periods average, the three-prior-periods average, and the four-prior-periods average of these variables as alternate measures of path-deepening search.

\section{Science-technology linkage}

Since it is possible that firms are more likely to search the science base if they are active in areas where technological knowledge alone may be inadequate for innovation, we include a control for 
Science-technology linkage in $_{\text {it }}$ in equations predicting Science search. We construct this variable by identifying all technological classes that each sample firm is active in, in a given year. We then compute the average rate of non-patent reference citations for all patents in the U.S. Patents Office in those classes in that year. Thus, if a firm was active in classes 2, 3, and 4 in a given year, we identified all patents in these three classes in that year and computed the proportion of these patents that cited non-patent references as the value of Science-technology linkage. High values of the variable indicate increased linkage to the science base.

\section{Firm-operational controls}

$\mathrm{R} \& \mathrm{D}$, firm performance, firm size, and product diversification are included in the equations as controls. We use logged R\&D expenditures as controls in both the search and the innovation models $\left(R \& D_{i t}\right)$. Prior research also suggests that poor performance can trigger changes in search behavior (Cyert and March, 1963; Audia, Locke, and Smith, 2000). Accordingly, we use return on assets for each firm yearly as a control for differences in performance (Firm performance ${ }_{i t}$ ). Firm size sit $_{i}$ serves as an indicator of the resources available for the search activities, and is measured as the natural $\log$ of the number of employees for each firm yearly. Finally, since diversified firms have more possibilities to exploit new knowledge and more possibilities to benefit from user innovation, we control for product diversification (Product diversification ${ }_{i t}$ ) using a Blau Index. Product sales in the 4-digit SIC codes for each firm yearly are used to construct this variable. For some firmyears, $R \& D$ or product diversification data were unavailable; in such cases we imputed these values based on adjacent years.

\section{Technological opportunity}

The degree of technological opportunity can also vary across technologies (Henderson and Cockburn, 1994). Some firms may be active in relatively 'richer' technological classes than other firms, and therefore perhaps have higher subsequent patenting in those domains. To control for this possibility, we included a Technological opportunity it $_{\text {variable. }}$ For each firm we identified the technology classes that it was active in, in any year. We then computed the number of total patents issued in these classes by the U.S. Patents Office and used that number as an indicator of the relative richness of the firm's specific environment. This variable is a control in the models predicting Firm innovation.

\section{Technology breadth}

We control for a firm's breadth of technological search-the traditional dimension of innovation search (Rosenkopf and Nerkar, 2001) - through the Blau Index of the firm's patenting across patent technology classes yearly. The U.S. patent system identifies almost 400 distinct technology classes. Each technology class reflects a specific area of technology in the same way that an SIC code reflects a certain product market area (Patel and Pavitt, 1997). The broader the scope of a firm's technological activity, the more likely it is to patent in many distinct classes, and possibly the more likely it is to innovate more. This variable is a control in the models predicting Firm innovation.

\section{Technology age}

The temporal dimension of search may also influence innovative output - for instance, building on older technologies may be less productive. Thus, we control for the age of the foundations of each firm's current-period innovations. Technology $a g e_{i t}$ is defined as the average age of the priorart patents that are cited in a given firm's yearly patents (Bierly and Chakrabarti, 1996; Katila, 2002; Nerkar, 2003). The age of a cited patent was the time elapsed since its issue. This variable is a control in the models predicting Firm innovation.

We also include dummy variables for each year to control for the possibility of period effects. All independent and control variables are lagged by 1 year (or more, as in the case of the multiple year lags in the search equations), relative to the dependent variable.

\section{Model estimation}

Our hypotheses on resource heterogeneity address both the antecedents and the consequences of search. Accordingly, we estimate two sets of models. The first set of models addresses the determinants of search (Science and Geography Search Models). The second set of models examines the 
impact of search on the innovativeness of the firm (Firm Innovation Model).

For the Search Models we use linear panel GLS regressions. In the Innovation Model the dependent variable is a count of innovation, Firm innovation $_{i t+1}$. Since this variable takes only discrete non-negative integer values, we use Poisson and negative binomial models that are appropriate for such data. To address the possibilities of unobserved heterogeneity and autocorrelation we use panel Poisson and negative binomial specifications (Hausman, Hall, and Griliches, 1984).

\section{RESULTS}

Tables 1, 2, and 3 present descriptive statistics and correlations for all variables in the Science Search, Geography Search, and Firm Innovation Models, respectively. The descriptive statistics indicate that the firms are characterized by a

Table 1. Descriptive statistics and correlations (Science Search Model)

\begin{tabular}{|c|c|c|c|c|c|c|c|c|c|c|}
\hline & Mean & S.D. & Min. & Max. & 1 & 2 & 3 & 4 & 5 & 6 \\
\hline 1 Science search $_{i t+1}$ & 1.19 & 1.01 & 0.00 & 7.00 & & & & & & \\
\hline 2 Technology exhaustion $_{i t}$ & 8.19 & 4.46 & 0.00 & 51.67 & 0.29 & & & & & \\
\hline 3 Science search $_{i t}^{\mathrm{a}}$ & 1.14 & 0.99 & 0.00 & 7.00 & 0.57 & 0.32 & & & & \\
\hline 4 Science-technology linkage $_{i t}$ & 0.32 & 0.07 & 0.05 & 0.54 & 0.45 & 0.06 & 0.49 & & & \\
\hline 5 Firm size $_{i t}{ }^{\mathrm{a}}$ & 2.89 & 1.04 & 0.88 & 5.18 & -0.08 & -0.13 & -0.04 & -0.20 & & \\
\hline $6 R \& D_{i t}^{\mathrm{a}}$ & 4.25 & 1.32 & 0.81 & 7.15 & 0.19 & -0.02 & 0.23 & 0.22 & 0.76 & \\
\hline 7 Firm performance $_{i t}$ & 0.06 & 0.05 & -0.13 & 0.24 & 0.01 & 0.08 & 0.04 & 0.05 & -0.23 & -0.03 \\
\hline
\end{tabular}

${ }^{\mathrm{a}}$ Logarithm

$\mathrm{N}=302$

Table 2. Descriptive statistics and correlations (Geography Search Model)

\begin{tabular}{lccrrrrrrr}
\hline & Mean & S.D. & Min. & Max. & 1 & 2 & 3 & 4 & 5 \\
\hline 1 Geography search $_{i t+1}$ & 0.002 & 0.14 & -0.56 & 0.56 & & & & & \\
2 International product-market change $_{i t}$ & -0.26 & 2.99 & -18.00 & 8.00 & -0.13 & & & & \\
3 Geography search $_{i t}$ & 0.002 & 0.14 & -0.56 & 0.56 & -0.52 & 0.17 & & & \\
4 R\&D $^{a}{ }^{a}$ & 4.25 & 1.32 & 0.81 & 7.15 & -0.01 & 0.01 & 0.04 & \\
5 Firm size $_{i t}{ }^{a}$ & 2.89 & 1.04 & 0.88 & 5.18 & 0.04 & 0.02 & 0.04 & 0.75 & \\
Firm performance $_{i t}$ & 0.06 & 0.05 & -0.13 & 0.24 & -0.04 & -0.01 & -0.01 & 0.006 & -0.21 \\
\hline
\end{tabular}

${ }^{\mathrm{a}}$ Logarithm

$\mathrm{N}=216$

Table 3. Descriptive statistics and correlations (Firm Innovation Model)

\begin{tabular}{|c|c|c|c|c|c|c|c|c|c|c|c|c|}
\hline & Mean & S.D. & Min. & Max. & 1 & 2 & 3 & 4 & 5 & 6 & 7 & 8 \\
\hline 1 Firm $_{\text {innovation }}{ }_{i t+1}$ & 97.63 & 129.06 & 0.00 & 760.00 & & & & & & & & \\
\hline $2{\text { Science } \text { search }_{i t}(00 \mathrm{~s})}$ & 1.30 & 2.01 & 0.00 & 11.60 & 0.86 & & & & & & & \\
\hline 3 Geography search & 0.09 & 0.11 & 0.00 & 0.56 & 0.24 & 0.27 & & & & & & \\
\hline 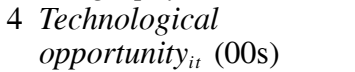 & 131.69 & 110.73 & 1.17 & 568.24 & 0.89 & 0.83 & 0.28 & & & & & \\
\hline 5 Technology breadth ${ }_{i t}$ & 0.82 & 0.24 & 0.00 & 0.98 & 0.37 & 0.31 & 0.08 & 0.50 & & & & \\
\hline 6 Technology age $_{i t}$ & 10.75 & 2.59 & 2.75 & 29.71 & -0.18 & -0.13 & -0.03 & -0.20 & -0.18 & & & \\
\hline 7 Product diversification $_{i t}$ & 0.67 & 0.18 & 0.00 & 1.00 & 0.27 & 0.24 & 0.07 & 0.27 & 0.21 & -0.22 & & \\
\hline $8 R \& D_{i t}^{\mathrm{a}}$ & 4.25 & 1.32 & 0.81 & 7.15 & 0.78 & 0.72 & 0.33 & 0.79 & 0.43 & -0.24 & 0.22 & \\
\hline 9 Firm performance $_{i t}$ & 0.06 & 0.05 & -0.13 & 0.24 & -0.07 & -0.03 & -0.11 & -0.10 & -0.05 & 0.08 & -0.16 & -0.01 \\
\hline
\end{tabular}

${ }^{\mathrm{a}}$ Logarithm

$\mathrm{N}=281$ 
significant diversity on variables such as Science search, Geography search, Firm innovation, $R \& D$, and Firm size.

Table 4 presents the results predicting Science search $_{i t+1}$ using a panel random effects GLS specification. Model 1 in Table 4 includes the control variables, and in Models 2, 3, 4, and 5 we add the four lagged values, $(t, t-1, t-2, t-3)$ of the hypothesized effect (Technology exhaustion), respectively. Models 2-5 indicate that the 1 period lagged and 3 period lagged values of technology exhaustion are positive and significant, as predicted. In Model 6 we enter all lags simultaneously into the equation. Again the 1 period and 3 period lagged values remain positive and significant. Thus, technological exhaustion, as proposed in Hypothesis 1, appears to prompt increased search of the science base with a lag of 1-3 years. Among the control variables, the measure for pathdeepening search, i.e., Science search ${ }_{i t}$, is consistently positive and significant. In summary, these results suggest that firms react to opportunities and problems in their environments and, in the case of science search, with a fairly short lag.
The corresponding models that examine the predictors of Geography search ${ }_{i t+1}$ are presented in Table 5. Again, Model 1 includes the control variables, Models 2 through 5 add the four lagged values of the hypothesized effect (International product-market change), respectively, while Model 6 presents all four lagged variables included simultaneously in the equation. Models 2-6 suggest support for our prediction in Hypothesis 2. Specifically, we find that firms do react to changes in their international product-market presence by changing their international research presence; however, this occurs with a significant (4year) lag. As Models 2-5 indicate, only the 4-year lagged variable is significant. Model 6, in which all lags are entered simultaneously, also indicates the same conclusion: there is a positive and significant effect of international product-market change on changes in international research presence after 4 years. In Models 2-6, the variables reflecting path-deepening tendencies in search (i.e., the lagged value of Geography search) also present an interesting story. These results suggest that, controlling for other factors, firms that undertake

Table 4. Random effects panel GLS regression predicting Science search $_{i t+1}$

\begin{tabular}{|c|c|c|c|c|c|c|}
\hline Variable & 1 & 2 & $3^{\wedge}$ & $4^{\wedge}$ & 5 & $6^{\wedge}$ \\
\hline Intercept & $\begin{array}{r}-0.14 \\
0.36\end{array}$ & $\begin{array}{r}-0.47 \\
0.38\end{array}$ & & & $\begin{array}{r}-0.06 \\
0.55\end{array}$ & \\
\hline Technology & & $0.03^{* *}$ & & & & $0.03^{*}$ \\
\hline exhaustion $_{i t}$ & & 0.01 & & & & 0.02 \\
\hline Technology & & & 0.01 & & & -0.01 \\
\hline exhaustion $_{i t-1}$ & & & 0.01 & & & 0.02 \\
\hline Technology & & & & $0.03^{*}$ & & $0.03^{*}$ \\
\hline exhaustion $_{i t-2}$ & & & & 0.01 & & 0.02 \\
\hline Technology & & & & & 0.02 & -0.005 \\
\hline exhaustion $_{i t-3}$ & & & & & 0.02 & 0.02 \\
\hline \multirow[t]{2}{*}{ Science search ${ }_{i t}$} & $0.47^{* * *}$ & $0.42^{* * *}$ & $0.45^{* * *}$ & $0.44^{* * *}$ & $0.42^{* * *}$ & $0.41^{* * *}$ \\
\hline & 0.06 & 0.06 & 0.07 & 0.07 & 0.07 & 0.08 \\
\hline Science-technology & $1.99 \dagger$ & $2.54^{*}$ & $2.16 \dagger$ & $2.05 \dagger$ & 2.07 & $2.53 \dagger$ \\
\hline linkage $_{i t}$ & 1.04 & 1.05 & 1.11 & 1.20 & 1.34 & 1.37 \\
\hline \multirow[t]{2}{*}{${\text { Firm } \text { size }_{i t}}$} & $-0.17 \dagger$ & $-0.15 \dagger$ & $-0.18 \dagger$ & $-0.20 \dagger$ & $-0.23^{*}$ & $-0.20 \dagger$ \\
\hline & 0.09 & 0.09 & 0.10 & 0.10 & 0.12 & 0.12 \\
\hline \multirow[t]{2}{*}{$R \& D_{i t}$} & $0.14^{*}$ & $0.14^{*}$ & $0.15^{*}$ & $0.16 \dagger$ & $0.18 \dagger$ & $0.17 \dagger$ \\
\hline & 0.07 & 0.07 & 0.08 & 0.08 & 0.09 & 0.09 \\
\hline \multirow[t]{2}{*}{ Firm performance $_{i t}$} & -0.27 & -0.53 & -0.37 & -0.43 & -0.53 & -0.45 \\
\hline & 1.25 & 1.25 & 1.33 & 1.40 & 1.51 & 1.49 \\
\hline$R^{2}$ & 0.41 & 0.42 & 0.39 & 0.37 & 0.34 & 0.36 \\
\hline$N$ & 302 & 302 & 279 & 256 & 233 & 233 \\
\hline
\end{tabular}

$\dagger p<0.1 ;{ }^{*} p<0.05 ;{ }^{* *} p<0.01 ;{ }^{* * *} p<0.001$ (one-tailed tests for hypothesized variables, two-tailed tests for controls).

The table gives parameter estimates; standard errors are below each parameter estimate. Year dummies are included, but not shown. For models with lagged variables Stata randomly drops either the intercept or one of the year dummies. ${ }^{\wedge}$ indicates models in which the intercept was dropped. 
Table 5. Random effects GLS regression predicting Geography $\operatorname{search}_{i t+1}$

\begin{tabular}{|c|c|c|c|c|c|c|}
\hline Variable & 1 & 2 & $3^{\wedge}$ & 4 & $5^{\wedge}$ & 6 \\
\hline \multirow{2}{*}{ Intercept } & 0.01 & -0.02 & & -0.01 & & -0.01 \\
\hline & 0.04 & 0.04 & & 0.04 & & 0.04 \\
\hline \multirow[t]{2}{*}{ International product-market change $_{i t}$} & & -0.002 & & & & -0.001 \\
\hline & & 0.003 & & & & 0.003 \\
\hline \multirow{2}{*}{ International product-market change $_{i t-1}$} & & & -0.0003 & & & -0.0007 \\
\hline & & & 0.003 & 00002 & & $\begin{array}{c}0.003 \\
-0.0005\end{array}$ \\
\hline International product-market change $_{i t-2}$ & & & & 0.003 & & 0.003 \\
\hline \multirow[t]{2}{*}{ International product-market change $_{i t-3}$} & & & & & $0.01^{*}$ & $0.01^{*}$ \\
\hline & & & & & 0.003 & 0.003 \\
\hline \multirow[t]{2}{*}{ Geography search ${ }_{i t}$} & $-0.53^{* * *}$ & $-0.50^{* * *}$ & $-0.52^{* * *}$ & $-0.47^{* * *}$ & $-0.39^{* * *}$ & $-0.39^{* * *}$ \\
\hline & 0.05 & 0.06 & 0.06 & 0.06 & 0.07 & 0.07 \\
\hline \multirow{2}{*}{ Firm size $_{i t}$} & 0.002 & 0.01 & -0.004 & 0.001 & -0.00005 & 0.0005 \\
\hline & 0.01 & 0.01 & 0.01 & 0.01 & 0.01 & 0.01 \\
\hline \multirow[t]{2}{*}{$R \& D_{i t}$} & -0.0003 & -0.002 & 0.01 & 0.002 & -0.001 & -0.001 \\
\hline & 0.01 & 0.01 & 0.01 & 0.01 & 0.01 & 0.01 \\
\hline \multirow[t]{2}{*}{ Firm performance $_{i t}$} & -0.19 & -0.23 & -0.25 & -0.25 & -0.07 & -0.06 \\
\hline & 0.18 & 0.20 & 0.20 & 0.19 & 0.22 & 0.23 \\
\hline$R^{2}$ & 0.31 & 0.32 & 0.33 & 0.32 & 0.27 & 0.27 \\
\hline$N$ & 286 & 216 & 191 & 166 & 141 & 141 \\
\hline
\end{tabular}

$\dagger p<0.1$; $^{*} p<0.05 ;{ }^{* *} p<0.01$; ${ }^{* * *} p<0.001$ (one-tailed tests for hypothesized variables, two-tailed tests for controls).

The table gives parameter estimates; standard errors are below each parameter estimate. Year dummies are included, but not shown. For models with lagged variables Stata randomly drops either the intercept or one of the year dummies. ${ }^{\wedge}$ indicates models in which the intercept was dropped.

significant expansions into new international research locations in one period are likely to partially reverse these actions in subsequent years. We return to this intriguing finding in the discussion section.

Finally, Table 6 presents the results predicting Firm innovation $_{i t+1}$. Control variables are included in blocks in Models 1 and 2 (Firm-Operational and Firm-Technology controls, respectively). Models 3 and 4 include the hypothesized variables, Science search and Geography search, entered separately along with their squared terms. Model 5 includes all variables, and provides support for both Hypotheses 3 and 4. In Hypothesis 3 we predicted a curvilinear relationship between science search and innovativeness with innovation output increasing with increasing science search up to a point and then decreasing. This hypothesis was supported. The coefficient on Science search was positive and significant, while the coefficient on its squared term was negative and significant. Similarly, in Hypothesis 4 we predicted an inverted U relationship between geography search and innovativeness. This prediction was borne out as well, as the coefficient on Geography search was positive and significant, while the coefficient on its squared term was negative and significant. Thus, to promote innovation, firms should explore enough to create variety, yet not too much to lose control. In both these cases calculation of the point of inflection on the respective curves indicated that the downward part of the curve was indeed observed in the data. For science search, our variable ranges from 0 to 1160, and using the coefficients in Model 5 we can calculate the point of inflection at approximately $737[(0.0008) /(2 * 5.43 \mathrm{e}-07)]$, while on geography search the range was from 0 to 0.56 , and the point of inflection was at 0.17 [1.42/2*4.16]. Thus, we observe firms on both sides of the inflection points, both undershooting and overshooting the optimal level of search. For the geography search variable both rising and declining parts of the curve seem to be identified with some clarity - the inflection point is less than one standard deviation from the mean, and at some distance away from each tail. However, in the case of science search, the downward part of the $U$ shape has significantly fewer observations than the upward part, and the point of inflection is more than three standard deviations beyond the mean. Therefore, we cannot say with complete confidence whether the relationship is curvilinear or in 


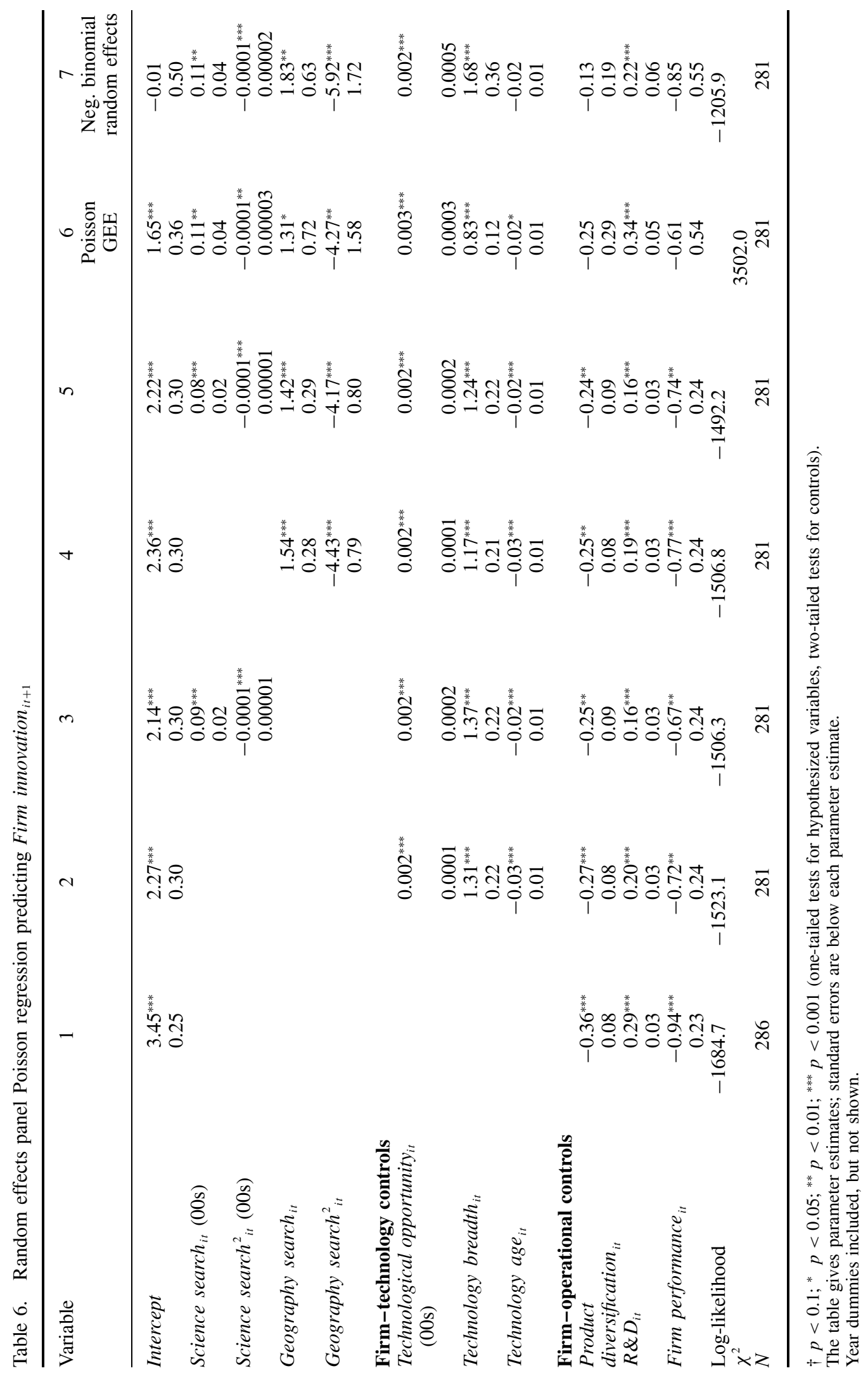


fact simply exhibits diminishing returns. To distinguish between these two possibilities we replaced the original science search variables with a logged variable in unreported regressions. If the logged variable were to be a significantly poor fit, for instance if it were to drop from significance, we could be more confident that the curvilinear specification was a significantly better fit. However, the logged variable was positive and significant (while other results remained unchanged) and thus we were unable to conclusively resolve this issue. Thus, it appears that science search does impact innovation output positively but with diminishing returns. Whether these diminishing returns eventually lead to a curvilinear (inverted $\mathrm{U}$ ) shape or plateau off asymptotically could not be clearly distinguished.

We also estimated a number of additional models for robustness. For the Firm Innovation Model, we report generalized estimating equations (GEE) Poisson models with Huber/White robust standard errors (Liang and Zeger, 1986) and panel negative binomial regression in Table 6 in Models 6 and 7. Furthermore, since patents can vary in their value, we also estimated models where citationweighted patents (forward citations that the firm's patents receive after issue) were used as a dependent variable in place of simple counts of patents (Trajtenberg, 1990). For the Search Models, in unreported regressions we used alternative measures of path-deepening search in the two search models (lags of varying length from 1 to 4 prior periods were averaged to create the variable). Since the search equations included lagged values of the dependent variable as regressors we also estimated both search models using an instrumental variables regression approach. These additional tests provided further support to the original findings.

\section{DISCUSSION}

In this paper we explored the question of the origins of resource heterogeneity in the context of global technological capability acquisition. Prior research has identified the importance of pathdeepening searches through which firms' inertia or momentum drives them along certain paths that eventually lead to the building of specific resource endowments (Amburgey and Miner, 1992; Karim and Mitchell, 2000). This literature has, however, not explained what causes firms to initiate journeys along these diverse paths in the first place. In this study, we complemented the path-deepening focus of this prior research by drawing attention to path-creating search behavior that initiates resource heterogeneity. Specifically, we argued, and found empirical support for the argument that resource heterogeneity can originate through pathcreating search processes. Our support for this thesis consisted of two parts. In the first part, we found that firms respond to stimuli in the form of problems and opportunities in their idiosyncratic situations. When faced with technological exhaustion, firms expanded their scientific activities. Similarly, when international expansion expanded the geographic footprint of a firm's product-markets, firms responded with an expansion of their international research presence. In the second part of the study, we established that the variations in behavior that constitute such path-creating activities, the intensity of a firm's science search or the diversity of its geographic search, can indeed lead to performance-enhancing outcomes, at least up to a point. We next turn to the theoretical and research implications of these arguments and findings.

\section{Implications for theory and research}

\section{The resource-based view of the firm}

One of the fundamental tenets of the resourcebased view is that competitive advantage stems from resource heterogeneity between firms and from the sustainability of this heterogeneity over time. Yet, the resource-based view is less forthcoming on how such resource heterogeneity arises (but see Helfat and Lieberman, 2002, and Zott, 2003, for work that has started to examine this issue). Our focus on path-creating search highlights one potential source of resource heterogeneity: firms' solutions to the idiosyncratic situations faced by them can eventually transform into performance-enhancing capabilities. For instance, an expansion of research effort overseas that serves as a corollary to a product-market expansion can eventually become a source of enhanced innovative productivity. Thus, variety in the problems and opportunities faced by firms can translate to variety in their resource bases. 


\section{Evolutionary search and change}

Although our focus was on path-creating search, we also identified some intriguing results vis-à-vis path-deepening search. Specifically, we found that while on average firms tend to persist in similar activities (witness the positive effect of prior science search on subsequent science search), at the margin they are quite capable of reversing directions (as indicated by the negative effect of prior geographic search expansions on subsequent ones). While explaining this result formally is beyond the scope of this study, the result and the evolutionary theorizing from which it draws raise an intriguing possibility. We noted in the second half of the paper that, especially for geography search and less definitively so for science, the relation between innovative and search activity was curvilinear. For researchers to be able to statistically identify a curve of this fashion, firms must be distributed along the spectrum of search possibilities, some oversearching and some undersearching, but not all clustered around the optimal point. If this is the case, one explanation of the negative relationship between prior and subsequent geography search expansions could be quite simply that firms find it difficult to identify the optimal level of search (Nelson and Winter, 1982). During the course of building their resource positions, firms make mistakes. For instance, a firm's expansion of its international research presence may first promote innovation as new paths are created, yet result in suboptimally high investments, and reversal in direction, as paths are extended extensively. These results thus highlight the value of finding a balance between exploitation and exploration (Tushman and O'Reilly, 1996; Katila and Ahuja, 2002; Rivkin and Siggelkow, 2003), yet also go further, to support recent theorizing on organizations as complex adaptive systems (e.g., Kauffman, 1993), and the idea that many innovative organizations live at the 'edge of chaos' where the system is inherently inefficient, 'stumbling into the wrong markets, making mistakes, and bouncing back' (Brown and Eisenhardt, 1998: 8).

The results also answer, and perhaps also raise, interesting questions about the dynamics of organizational change. Prior work generally argues that search behavior is both inertial (firms resist change) and exhibits momentum (once change is initiated, organizations keep changing in the same direction). On the one hand, our results indicate that idiosyncratic problems and opportunities can initiate change - thus organizations may not be as inert as they are sometimes claimed to be (Hannan and Freeman, 1989). On the other hand, our results show that once change is initiated it proceeds down, but also up, a given path - thus we find limits for the momentum argument (Miller and Friesen, 1980). In fact, organizations searching the geographic space appeared to take a step backward for every two steps forward. These findings raise interesting issues for future work.

\section{Innovation search}

Our findings also have important implications for research on innovation search. The existing literature on search has focused largely on search across technologies (Rosenkopf and Nerkar, 2001; Katila and Ahuja, 2002), and found support for the thesis that firms generally engage in local search, that is, searching in the neighborhood of their existing technologies (Helfat, 1994). In this paper, we examined two types of behaviors that enabled firms to go beyond this type of local search: spanning the technology-science boundary, and spanning the national-international R\&D boundary. Our primary arguments, which also found empirical support, were that even after controlling for variations in the number of technologies explored by firms, the crossing of the additional boundaries, scientific and geographic, contributed to increases in innovative output.

Our findings on the drivers of search are also interesting. First, our results indicate that organizations need not necessarily be especially rich or poor (Cyert and March, 1963) to embark on new search paths; they just need to recognize that they are in the right place at the right time (i.e., recognize an idiosyncratic problem or an opportunity) to start a new search (cf. Shane and Venkataraman, 2000). Second, past commitments can also drive search in unexpected ways. For example, we find that organizations in the geography space frequently retract from search commitments, perhaps to correct past mistakes in a search-a driver of search that deserves more attention in future work.

Going further into the individual dimensions of search, our finding that searching the science base enhances innovativeness is complementary to another perspective on the science-technology relationship. Scholars have argued that firms may benefit from engaging in science because that 
allows firms to attract talented scientists at lower cost (Stern, 1999). Although our data do not allow us to speak to the cost side of this issue, the results do indicate that supporting science may also benefit innovative productivity. On the geography side, our finding that international product-market presence increases international research, and eventually promotes innovation, draws attention to an interesting aspect of multinationality. Although our study focused on the two dimensions of non-local innovation search, our results suggest that perhaps even relatively highly diversified international research presence can eventually be quite consistent with the idea of local search. The key to understanding this lies in the recognition that the modern multinational firm has potentially many geographic neighborhoods (Dunning, 1992). Even if each firm is constrained to search in only its immediate geographic vicinity, the large multinational firm that has wide product-market presence has the advantage of being 'local' to many neighborhoods, and hence has the ability to realize the benefits of diversified product-market presence by expanding its research presence to the locations where it is already present - an advantage which may not be available to more geographically focused firms.

\section{Limitations and future work}

The study naturally also has limitations. First, one inherent limitation of this study is the measurement of resource heterogeneity. While we were able to show that the outcomes of path-creating search processes were performance-enhancing and thus potential capabilities, we were limited in our ability, in the same way as previous authors have been (e.g., Cockburn et al., 2000), to specifically demonstrate that we had been able to measure the elusive concept of heterogeneous resources. Despite this limitation we made an important step towards understanding the emergence of resources, and thus set the stage for future studies on resource creation. Empirically this study was also restricted to inferring search processes from the paper-trail left in archival documents. Direct observation and measurement of such processes (e.g., Graebner, 2004) could immensely enrich and improve our findings. Unfortunately, the temporal sweep required to observe search behavior and its consequences is so large that accomplishing this on a large statistical sample scale is likely to be prohibitive. Similarly, the restriction of this study to a single nation, and to a single industry, is a mixed blessing. On the one hand, this context limits unobserved heterogeneity and makes possible more systematic and unbiased comparisons, thereby enhancing internal validity. On the other hand, this context limitation also suggests caveats in terms of generalizability. Again, the intensity of data collection, especially regarding the science search variables that are extremely labor-intensive to collect, imposed this constraint. Thus, one possibility for future work is to examine other nationindustry contexts.

\section{Conclusion}

At the beginning of this study, we set out to investigate the emergence of resources. We noted that the origins of resources were not well understood. Yet, the question is important if we want to understand the processes through which firms create competitive advantage. Our results, found in the context of technological capability acquisition, showed that the emergence of resources was inherently an evolutionary process: idiosyncratic, inertial; yet path-breaking on occasion; and prone to mistakes. Our results indicate that heterogeneity emerged when the search paths that firms followed were unique responses to idiosyncratic situations they faced. We focused on two such idiosyncratic circumstances: problems and opportunities that firms faced in their local innovation searches. As a response to these situations, firms created unique science and geography search paths that were likely to lead to the creation of heterogeneous resources. We also found that firms experimented in order to find the correct investment down each of these paths, and frequently made mistakes in undershooting and overshooting the most productive levels, further demonstrating the evolutionary nature of the resource creation process. We hope that these results lead to a more complete understanding of the variety of processes that underlie resource heterogeneity.

\section{ACKNOWLEDGEMENTS}

We appreciate the insightful comments and suggestions of the Special Issue editors and the two reviewers, and gratefully acknowledge the financial support of the University of Texas at Austin, the University of Maryland, the University of 
Michigan Business School, and the Stanford Technology Ventures Program. The research was also supported in part by the National Science Foundation Grant (\#0115147) for the second author. Seminar audiences at the University of Pittsburgh and Dartmouth provided great feedback, and Benjamin Hallen, Jennifer Marrone, and Qing Cao valuable research assistance.

\section{REFERENCES}

Abernathy W, Utterback J. 1978. Patterns of industrial innovation. Technology Review 50: 41-47.

Achilladelis B, Schwarzkopf A, Cines M. 1987. A study of innovation in the pesticide industry: analysis of the innovation record of an industrial sector. Research Policy 16(2-4): 175-212.

Ahuja G. 2000a. Collaboration networks, structural holes, and innovation: a longitudinal study. Administrative Science Quarterly 45: 425-455.

Ahuja G. 2000b. The duality of collaboration: inducements and opportunities in the formation of interfirm linkages. Strategic Management Journal 21(3): 317-344.

Ahuja G, Katila R. 2001. Technological acquisitions and the innovation performance of acquiring firms: a longitudinal study. Strategic Management Journal 22(3): 197-220.

Ahuja G, Lampert C. 2001. Entrepreneurship in the large corporation. Strategic Management Journal, Special Issue 22(6-7): 521-543.

Allen T. 1977. Managing the Flow of Technology: Technology Transfer and the Dissemination of Technological Information within the R\&D Organization. MIT Press: Cambridge, MA.

Almeida P. 1996. Knowledge sourcing by foreign multinationals: patent citation analysis in the U.S. semiconductor industry. Strategic Management Journal, Winter Special Issue 17: 155-165.

Almeida P, Kogut B. 1999. Localization of ideas and the mobility of engineers in regional networks. Management Science 45: 905-917.

Almeida P, Song J, Grant R. 2002. Are firms superior to alliances and markets? An empirical test of crossborder knowledge building. Organization Science 13: 147-161.

Amburgey T, Miner A. 1992. Strategy momentum: the effects of repetitive, positional, and contextual momentum on merger activity. Strategic Management Journal 13(5): 335-348.

Arora A, Landau R, Rosenberg N. 1998. Introduction. In Chemicals and Long-Term Economic Growth: Insights from the Chemical Industry, Arora A, Landau R, Rosenberg N (eds). Wiley: New York; 3-24.

Arora A, Rosenberg N. 1998. Chemicals: A U.S. success story. In Chemicals and Long-Term Economic Growth: Insights from the Chemical Industry, Arora A, Landau R, Rosenberg N (eds). Wiley: New York; 71-102.
Audia P, Locke E, Smith K. 2000. The paradox of success: an archival and a laboratory study of strategic persistence following radical environmental change. Academy of Management Journal 43: 837-853.

Bantel K, Jackson S. 1989. Top management and innovations in banking: does the composition of the top team make a difference? Strategic Management Journal, Summer Special Issue 10: 107-124.

Barney J. 1991. Firm resources and sustained competitive advantage. Journal of Management 17: 99-120.

Barr P, Stimpert J, Huff A. 1992. Cognitive change, strategic action, and organizational renewal. Strategic Management Journal, Summer Special Issue 13: 15-36.

Berman S, Down J, Hill C. 2002. Tacit knowledge as a source of competitive advantage in the national basketball association. Academy of Management Journal 45: 13-31.

Bierly P, Chakrabarti A. 1996. Generic knowledge strategies in the U.S. pharmaceutical industry. Strategic Management Journal, Winter Special Issue 17: $123-135$.

Blau P. 1977. Inequality and Heterogeneity: A Primitive Theory of Social Structure. Free Press: New York.

Brown S, Eisenhardt K. 1998. Competing on the Edge: Strategy as Structured Chaos. Harvard Business School Press: Boston, MA.

Carpenter P, Cooper M, Narin F. 1980. Linkage between basic research literature and patents. Research Management 13(2): 30-35.

Cockburn I, Henderson R, Stern S. 2000. Untangling the origins of competitive advantage. Strategic Management Journal, Special Issue 21(10-11): 1123-1145.

Cohen M, March J, Olsen J. 1972. A garbage can model of organizational choice. Administrative Science Quarterly 17(1): 1-25.

Cyert R, March J. 1963. A Behavioral Theory of the Firm. Prentice-Hall: Englewood Cliffs, NJ.

De Meyer A. 1992. Management of international R\&D operations. In Technology Management and International Business: Internationalization of $R \& D$ and Technology, Granstrand O, Hakanson L, Sjolander S (eds). Wiley: New York; 163-178.

Dougherty D. 1992. A practice-centered model of organizational renewal through product innovation. Strategic Management Journal, Summer Special Issue 13: 77-92.

Dunning J. 1992. Multinational Enterprises and the Global Economy. Addison-Wesley: Reading, MA.

Eisenhardt K, Martin J. 2000. Dynamic capabilities: what are they? Strategic Management Journal, Special Issue 21(10-11): 1105-1121.

Eisenhardt K, Schoonhoven K. 1990. Organizational growth: linking founding team, strategy, environment, and growth among U.S. semiconductor ventures, 1978-1988. Administrative Science Quarterly 40: $84-110$.

Eisenhardt K, Tabrizi B. 1995. Accelerating adaptive processes: product innovation in the global computer industry. Administrative Science Quarterly 40: 84-110. 
Feinberg S, Gupta A. 2004. Knowledge spillovers and the assignment of $\mathrm{R} \& \mathrm{D}$ responsibilities to foreign subsidiaries. Strategic Management Journal, Special Issue 25(8-9): 823-845.

Fleming L. 2001. Recombinant uncertainty in technological search. Management Science 47: 117-132.

Fredrickson J, Iaquinto A. 1989. Inertia and creeping rationality in strategic decision processes. Academy of Management Journal 32: 516-542.

Freeman C, Soete L. 1997. The Economics of Industrial Innovation. MIT Press: Cambridge, MA.

Galunic C, Rodan S. 1998. Resource recombinations in the firm: knowledge structures and the potential for Schumpeterian innovation. Strategic Management Journal 19(12): 1193-1201.

Ghemawat P. 2001. Distance still matters. Harvard Business Review 79(8): 137-145.

Graebner M. 2004. Momentum and serendipity: how acquired leaders create value in the integration of hightech firms. Strategic Management Journal, Special Issue 25(8-9): 751-777.

Graebner M, Eisenhardt K. 2003. The other side of the story: seller decision-making in entrepreneurial acquisitions. Working paper, Stanford University.

Granstrand O, Hakanson L, Sjolander S. 1992. Internationalization of R\&D: a survey of some recent research. Research Policy 22: 413-430.

Griliches Z. 1979. Issues in assessing the contribution of R\&D to productivity growth. Bell Journal of Economics 10: 92-116.

Griliches Z. 1990. Patent statistics as economic indicators: a survey. Journal of Economic Literature 28: $1661-1707$.

Gupta A, Govindarajan V. 2000. Knowledge flows within multinational corporations. Strategic Management Journal 21(4): 473-496.

Hannan M, Freeman J. 1989. Organizational Ecology. Harvard University Press: Cambridge, MA.

Hansen M. 1999. The search-transfer problem: the role of weak ties in sharing knowledge across organization subunits. Administrative Science Quarterly 44: $82-111$.

Hansen M, Lovas B. 2004. How do multinational companies leverage technological competencies? Moving from single to interdependent explanations. Strategic Management Journal, Special Issue 25(8-9): 801-822.

Hargadon A. 2003. How Breakthroughs Happen: The Surprising Truth about How Companies Innovate. Harvard Business School Press: Boston, MA.

Hargadon A, Douglas Y. 2001. When innovations meet institutions: Edison and the design of the electric light. Administrative Science Quarterly 46: 476-501.

Hargadon A, Sutton R. 1997. Technology brokering and innovation in a product development firm. Administrative Science Quarterly 42: 716-749.

Hausman J, Hall B, Griliches Z. 1984. Econometric models for count data with an application to the patents-R\&D relationship. Econometrica 52: 909-938.

Helfat C. 1994. Evolutionary trajectories in petroleum firm R\&D. Management Science 40: 1720-1747.
Helfat C, Lieberman M. 2002. The birth of capabilities: market entry and the importance of pre-history. Industrial and Corporate Change 11: 725-760.

Helfat C, Raubitschek R. 2000. Product sequencing: coevolution of knowledge, capabilities, and products. Strategic Management Journal, Special Issue 21: 961-980.

Henderson R. 1994. The evolution of integrative capability: innovation in cardiovascular drug discovery. Industrial and Corporate Change 3: 607-630.

Henderson R, Clark K. 1990. Architectural innovation: the reconfiguration of existing product technologies and the failure of established firms. Administrative Science Quarterly 35(1): 9-30.

Henderson R, Cockburn I. 1994. Measuring competence? Exploring firm effects in pharmaceutical research. Strategic Management Journal, Winter Special Issue 15: $63-84$.

Holland JH. 1975. Adaptation in Natural and Artificial Systems. University of Michigan Press: Ann Arbor, MI.

Hood N, Young S. 1979. The Economics of Multinational Enterprise. Longman: New York.

Iansiti M, Clark K. 1994. Integration and dynamic capability: evidence from product development in automobiles and mainframe computers. Industrial and Corporate Change 3: 557-605.

Jaffe AB, Trajtenberg M, Henderson R. 1993. Geographic localization of knowledge spillovers as evidenced by patent citations. Quarterly Journal of Economics 108: 577-598.

Karim S, Mitchell W. 2000. Path-dependent and pathbreaking change: reconfiguring business resources following acquisitions in the U.S. medical sector, 1978-1995. Strategic Management Journal, Special Issue 21: 1061-1081.

Katila R. 2002. New product search over time: past ideas in their prime? Academy of Management Journal 45: 995-1010.

Katila R, Ahuja G. 2002. Something old, something new: a longitudinal study of search behavior and new product introductions. Academy of Management Journal 45: 1183-1194.

Katila R, Mang P. 2003. Exploiting technological opportunities: the timing of collaborations. Research Policy 32: 317-332.

Kauffman S. 1993. The Origins of Order: Self-Organization and Selection in Evolution. Oxford University Press: New York.

Kim D-J, Kogut B. 1996. Technological platforms and diversification. Organization Science 7: 283-301.

Klevorick A, Levin R, Nelson R, Winter S. 1995. On the sources and significance of interindustry differences in technological opportunities. Research Policy 24: 169-316.

Knott A M. 2003. Persistent heterogeneity and sustainable innovation. Strategic Management Journal 24(8): 687-705.

Kuemmerle W. 1999. Foreign direct investment in industrial research in the pharmaceutical and electronics industries. Research Policy 28: 179-193. 
Landau R, Arora A. 1999. The chemical industry: From the 1850s until today. Business Economics 34(4): $7-15$.

Levin R, Klevorick A, Nelson R, Winter S, Gilbert R, Griliches Z. 1987. Appropriating the returns from industrial research and development: comments and discussion. Brookings Papers on Economic Activity (3): $783-831$.

Levinthal D, March J. 1993. The myopia of learning. Strategic Management Journal, Winter Special Issue 14: $95-112$.

Lewin A, Long C, Carroll T. 1999. The co-evolution of new organizational forms. Organization Science 10: $535-550$.

Liang K-Y, Zeger SL. 1986. Longitudinal data analysis using generalized linear models. Biometrika 73: $13-22$.

Lounamaa P, March J. 1987. Adaptive coordination of a learning team. Management Science 33: 107-123.

Lundvall B. 1988. Innovation as an interaction process: from user-producer interaction to the national system of innovation. In Technical Change and Economic Theory, Dosi G, Freeman C, Soete L (eds). Pinter: London; 349-369.

March J. 1991. Exploration and exploitation in organizational learning. Organization Science 2: 71-87.

Martin J, Eisenhardt K. 2002. Cross-business synergy: recombination, modularity, and the multi-business team. Working paper, University of Texas at Austin.

Merton R. 1957. Priorities in scientific discovery: a chapter in the sociology of science. American Sociological Review 22: 635-659.

Meyer A. 1982. Adapting to environmental jolts. Administrative Science Quarterly 27: 537-551.

Miller D, Friesen P. 1980. Momentum and revolution in organizational adaptation. Academy of Management Journal 23: 591-614.

Narin F, Hamilton K, Olivastro D. 1997. The increasing linkage between U.S. technology and public science. Research Policy 26: 317-330.

Narin F, Noma E. 1985. Is technology becoming science? Scientometrics 7: 369-381.

Narin F, Noma E, Perry R. 1987. Patents as indicators of corporate technological strength. Research Policy 16(2-4): 143-155.

Nelson R. 1995. Recent evolutionary theorizing about economic change. Journal of Economic Literature 33: 48-90.

Nelson R, Winter S. 1982. An Evolutionary Theory of Economic Change. Harvard University Press: Cambridge, MA.

Nerkar A. 2003. Old is gold? The value of temporal exploration in the creation of new knowledge. Management Science 49: 211-230.

Nobel R, Birkinshaw J. 1998. Innovation in multinational corporations: control and communication patterns in international R\&D operations. Strategic Management Journal 19(5): 494-496.

Okhuysen G, Eisenhardt K. 2002. Integrating knowledge in groups: how formal interventions enable flexibility. Organization Science 13: 370-385.
Patel P, Pavitt K. 1997. The technological competencies of the world's largest firms: complex and pathdependent, but not much variety. Research Policy 26: $141-156$.

Peteraf M. 1993. The cornerstones of competitive advantage: a resource-based view. Strategic Management Journal 14(3): 179-191.

Podolny J, Stuart T. 1995. A role-based ecology of technological change. American Journal of Sociology 100: $1224-1260$.

Porter M. 1995. The Competitive Advantage of Nations. Free Press: New York.

Pouder R, St John C. 1996. Hot spots and blind spots: geographical clusters of firms and innovation. Academy of Management Review 21: 1192-1225.

Prescott JE, Gibbons PT. 1993. Global competitive intelligence: an overview. In Global Perspectives on Competitive Intelligence, Prescott JE, Gibbons PT (eds). Society of Competitive Intelligence Professionals: Alexandria, VA; $1-30$.

Rivkin J, Siggelkow N. 2003. Balancing search and stability: interdependencies among elements of organizational design. Management Science 49: 290-311.

Rosenberg N. 1990. Why do firms do basic research (with their own money)? Research Policy 19(2): 165-174.

Rosenkopf L, Nerkar A. 2001. Beyond local search: boundary-spanning, exploration, and impact in the optical disc industry. Strategic Management Journal 22(4): 287-306.

Schoonhoven C, Eisenhardt K, Lyman K. 1990. Speeding products to market: waiting time to first product introduction in new firms. Administrative Science Quarterly 35: 177-207.

Shane S, Venkataraman S. 2000. The promise of entrepreneurship as a field of research. Academy of Management Review 25: 217-226.

Shaver M. 1998. Accounting for endogeneity when assessing strategy performance: does entry mode choice affect FDI survival? Management Science 44: 571-586.

Stern S. 1999. Do scientists pay to be scientists? NBER Working Paper Series no. 7410. Cambridge, MA.

Stinchcombe A. 1965. Organizations and social structure. In Handbook of Organizations, March JG (ed). Rand McNally: Chicago, IL; 142-193.

Stuart T, Podolny J. 1996. Local search and the evolution of technological capabilities. Strategic Management Journal, Summer Special Issue 17: 21-38.

Teece D, Pisano G, Shuen A. 1997. Dynamic capabilities and strategic management. Strategic Management Journal 18(7): 509-533.

Trajtenberg M. 1990. Economic Analysis of Product Innovation: The Case of CT Scanners. Harvard University Press: Cambridge, MA.

Trajtenberg M. 2001. Innovation in Israel 1968-1997: a comparative analysis using patent data. Research Policy 30: 363-389.

Tushman M, O’Reilly C. 1996. Ambidextrous organizations: managing evolutionary and revolutionary change. California Management Review 38: 8-30. 
Tyre M, Orlikowski W. 1994. Windows of opportunity: temporal patterns of technological adaptation in organizations. Organization Science 5: 98-118.

Utterback J. 1994. Mastering the Dynamics of Innovation. Harvard University Press: Cambridge, MA.

Walker R. 1995. Patents as Scientific and Technical Literature. Scarecrow Press: Metuchen, NJ.

Wernerfelt B. 1984. A resource-based view of the firm. Strategic Management Journal 5(2): 171-180.
Zott C. 2003. Dynamic capabilities and the emergence of intraindustry differential firm performance: insights from a simulation study. Strategic Management Journal 24(2): 97-125.

Zucker L, Darby M, Brewer M. 1998. Intellectual human capital and the birth of U.S. biotechnology enterprises. American Economic Review 88: 290-306. 